\title{
Fluxo gênico em soja na Região Oeste do Paraná
}

\author{
Ivan Schuster(1), Elisa Serra Negra Vieira ${ }^{(1)}$, Hamilton Santana(1), Deise Sinhorati ${ }^{(1)}$, \\ Rosane Bezerra da Silva(1) e Marco Antonio Rott de Oliveira ${ }^{(1)}$
}

(1)Cooperativa Central de Pesquisa Agrícola, Caixa Postal 301, CEP 85813-450 Cascavel, PR. E-mail: ivan@coodetec.com.br,
esnegra@coodetec.com.br, hamilton@coodetec.com.br, deise.sinhorati@bol.com.br, rosane@coodetec.com.br, marco@coodetec.com.br

Resumo - Este trabalho teve o objetivo de avaliar o fluxo gênico em soja, na Região Oeste do Paraná. Foram semeados cinco círculos concêntricos, com a cultivar CD 219RR, que contém o gene CP4 EPSPS. Os círculos foram espaçados em $50 \mathrm{~cm}$, com círculo interno de diâmetro de $50 \mathrm{~cm}$. Externamente a estes, foi semeada a cultivar CD 211 (convencional), também em cinco círculos concêntricos, espaçados em $1 \mathrm{~m}$. As plantas da cultivar CD 211 foram colhidas e trilhadas individualmente, e as sementes semeadas novamente no campo. Após a emergência, foram obtidas 151.772 plântulas, as quais, com 15 dias, foram pulverizadas com $900 \mathrm{~g} \mathrm{ha}^{-1}$ de i.a. de glifosato. Após uma semana, plantas sobreviventes foram submetidas à análise de PCR, para verificar a presença do gene CP4 EPSPS. A taxa de fecundação cruzada foi de 0,61, 0,29, 0,23, 0,22 e 0,23\% respectivamente a 1, 2, 3, 4 e 5 m de distância das plantas geneticamente modificadas.

Termos para indexação: Glycine max, organismo geneticamente modificado, taxa de fecundação cruzada, escape gênico.

\section{Soybean gene flow in the Western Region of Paraná}

\begin{abstract}
The objective of this work was to evaluate soybean gene flow in the Western Region of Paraná. Five concentric circles were sowed with the CD 219RR cultivar, which contains the CP4 EPSPS gene. The circles were spaced in $50 \mathrm{~cm}$ and the central circle had $50 \mathrm{~cm}$ in diameter. Externally to the CD 219RR circles, five concentric circles were sowed with CD 211 cultivar, a no genetically modified soybean, spaced of $1 \mathrm{~m}$. The CD 211 plants were harvested and threshed separately and the seeds were sowed again. After the emergency, 151,772 seedlings were obtained, which with 15 days were sprayed with $900 \mathrm{~g} \mathrm{ha}^{-1}$ a.i. of glyphosate. After one week, the surviving plants were analysed by PCR to verify the CP4 EPSPS gene presence. The cross-pollinating rate was $0.61,0.29$, $0.23,0.22$ and $0.23 \%$ in $1,2,3,4$ and 5 m distance of the genetically modified plants, respectively.
\end{abstract}

Index terms: Glycine max, genetically modified organism, cross-pollinating rate, gene escape.

\section{Introdução}

A soja é a principal "commodity" agrícola do Brasil. O País é o segundo maior produtor mundial de soja, e o incremento da área cultivada com essa leguminosa vem crescendo a cada ano, com conseqüente aumento de produção. Na safra de 2005/2006, foram cultivados 22,23 milhões de hectares, com produção de 53,41 milhões de toneladas e uma produtividade média de $2.403 \mathrm{~kg} \mathrm{ha}^{-1}$ (Conab, 2006). Desse total, 9,4 milhões de hectares $(42,3 \%)$ foram cultivados com soja geneticamente modificada (GM), tolerante ao herbicida glifosato, um aumento de 4,4 milhões de hectares em relação à safra anterior, e um aumento de $313 \%$ em relação à safra 2003/2004, quando foram plantados 3 milhões de hectares de soja GM no país (James, 2004, 2005).
As principais causas dessa rápida adoção da tecnologia foram: a expectativa de redução no uso de herbicidas, possibilidade de plantio direto, flexibilidade de uso somente quando e onde necessário, menor impacto ambiental, favorecimento do manejo das lavouras, redução dos custos, diminuição das perdas de produção e, em decorrência disso, possibilidade de aumento de produtividade e estabilidade das lavouras (Kleba, 1998; Siqueira et al., 2004).

Um dos receios dos ambientalistas, em relação às cultivares GM, é de que elas possam chegar a áreas protegidas, tais como reservas ecológicas ou parques nacionais, e se tornar invasoras. Resultados de dez anos de observação e monitoramento de cultivares de canola, milho, beterraba e batata, em relação ao seu comportamento invasivo, demonstraram que 
nenhuma das cultivares, GM ou convencionais, cresceu de forma abundante em nenhum local. Pelo contrário, após o primeiro ano todas declinaram em consequiência de algum tipo de competição (Crawley et al., 2001). Embora esses resultados não possam isentar completamente a possibilidade de uma planta GM se tornar invasora, indicam que as plantas cultivadas têm pouca probabilidade de sobreviver fora de seu ambiente de cultivo, especialmente em ambientes de competição.

Outro receio, em relação às cultivares GM, é a possibilidade de os transgenes escaparem dessas cultivares e invadirem o genoma de populações silvestres, e assim, desequilibrarem o meio ambiente (Borém, 2001). No caso da soja, a possibilidade de fluxo gênico para outras espécies pode ser considerada nula, por não haver parentes silvestres no país (Borém \& Miranda, 2005). A única possibilidade de fluxo gênico, em soja, seria para outras lavouras de soja cultivada. Agricultores que cultivam soja convencional, destinada ao mercado certificado desse produto, têm manifestado a preocupação de que o aumento da área de cultivo de soja GM possa contaminar suas plantações, através do fluxo de pólen proveniente dessas lavouras.

O fluxo gênico entre culturas GM e convencional foi estudado recentemente para diversas culturas, tais como a soja (Abud et al., 2003), algodão (Shen et al., 2001) e batata (Conner \& Dale, 1996). No Brasil, o fluxo gênico em soja vem sendo estudado há mais de três décadas (Sediyama et al., 1970; Vernetti et al., 1972).

A soja é uma espécie autógama, que possui flores completas. No momento da polinização, as anteras formam um anel em volta do estigma. O pólen é, então, depositado diretamente no estigma, o que resulta em elevada taxa de autofecundação. A polinização ocorre, geralmente, no dia anterior à abertura das flores (Carlson \& Lersten, 2004), de modo que o estigma somente fica exposto após ter sido autopolinizado. As taxas de cruzamentos naturais variam de menos de 0,5\% até cerca de $1 \%$ (Sediyama et al., 1970; Vernetti et al., 1972; Borém, 1999), conforme a cultivar e o local. Por este motivo, é necessário que sejam geradas informações sobre o fluxo gênico na cultura da soja, em diferentes variedades e locais, a fim de que sejam fornecidos subsídios aos produtores e às agências certificadoras, para que possam estabelecer áreas de isolamento adequadas, que impeçam a contaminação de lavouras convencionais por pólen proveniente de lavouras com plantas GM.
O objetivo deste trabalho foi avaliar a taxa de fluxo gênico entre soja GM e convencional, no Município de Cascavel, no Oeste do Paraná.

\section{Material e Métodos}

O experimento foi instalado em Cascavel, PR (532 $27^{\prime} 19^{\prime \prime} \mathrm{O}$ e $24^{\circ} 57^{\prime} 21^{\prime \prime} \mathrm{S} ; 781 \mathrm{~m}$ de altitude), na safra agrícola de 2004/2005, em Latossolo Vermelho escuro.

Foram utilizadas as cultivares CD 219RR (GM) e CD 211 (convencional). A cultivar CD 219RR contém o gene CP4 EPSPS, derivado do evento 40-3-2 (Padgette et al., 1995), que lhe confere tolerância ao herbicida glifosato. A cultivar CD 211 é sensível a esse herbicida. As sementes certificadas de ambas as cultivares foram cedidas pela Coodetec, Cascavel, PR.

$\mathrm{O}$ experimento foi montado no formato de círculos concêntricos, com cinco linhas centrais com a cultivar CD 219RR, espaçadas de $50 \mathrm{~cm}$, e cinco círculos externos a estes, espaçados de $1 \mathrm{~m}$, com a cultivar CD 211 (Figura 1). Todas as plantas das cinco linhas de CD 211 foram identificadas, de forma que na avaliação das progênies foi possível detectar a posição de cada progênie no experimento. $\mathrm{Na}$ fase de colheita, todas as plantas de CD 211 (2.480 plantas no total), distantes de 1 a $5 \mathrm{~m}$ da cultivar CD 219RR, foram colhidas e trilhadas individualmente.

As sementes obtidas (237.218) foram novamente semeadas, tendo-se mantido a identificação de sua origem (círculo em que foram obtidas as sementes, e posição das progênies no círculo). Quinze dias após a emergência, todas as plântulas emergidas foram contadas e pulverizadas com $900 \mathrm{~g} \mathrm{ha}^{-1}$ de i.a. de glifosato. Dez dias após a pulverização, foram contadas as plantas sobreviventes.

Para determinar se as plântulas sobreviventes eram realmente GM, resultantes de fluxo gênico, suas folhas foram coletadas para análise de PCR. A extração de DNA foi realizada segundo Doyle \& Doyle (1990). As amplificações foram realizadas com os primers 35S-Af2/petu r1 F (TGATGTGATATCTCCACTGACG) e 35S-Af2/petu r1 R (TGTATCCCTTGAGCCATGTTGT), que amplificam a região que envolve parte do promotor e parte da região codificadora do peptídio-sinal, da construção que contém o gene CP4 EPSPS. As reações de amplificação foram realizadas em um volume total de $20 \mu \mathrm{L}$, com $20 \mathrm{mM}$ de Tris- $\mathrm{HCl}$ (pH 8,3), $50 \mathrm{mM}$ de $\mathrm{KCl}, 3 \mathrm{mM}$ de $\mathrm{MgCl}_{2}$, $125 \mu \mathrm{M}$ de cada um dos desoxinucleotídeos (dATP, dTTP, dGTP e dCTP), 0,4 $\mu \mathrm{M}$ de cada primer, uma uni- 
dade da enzima Taq DNA polimerase e $30 \mathrm{ng}$ de DNA. As amplificações foram realizadas em termociclador Termo Hybaid PCR Express, programado para uma etapa inicial de 3 min a $94^{\circ} \mathrm{C}$, seguida de 35 ciclos de $30 \mathrm{~s} \mathrm{a}$ $94^{\circ} \mathrm{C}, 30 \mathrm{~s}$ a $50^{\circ} \mathrm{C}$ e $42 \mathrm{~s}$ a $72^{\circ} \mathrm{C}$. Por fim, uma etapa de $10 \min$ a $72^{\circ} \mathrm{C}$.

Após a amplificação, as reações foram aplicadas em gel de agarose $3 \%$, coradas com brometo de etídio $\left(0,2 \mathrm{mg} \mathrm{mL}^{-1}\right)$, submetidas à eletroforese a $100 \mathrm{~V}$, por 2 horas e trinta minutos, e fotografados sob luz ultravioleta, em equipamento de fotodocumentação Vilber Lourmat. Em cada reação, foi incluído um controle positivo e um controle negativo.

Os resultados foram avaliados em porcentagem de plantas GM, obtidas a partir de sementes colhidas em plantas convencionais, em oito direções, nas distâncias

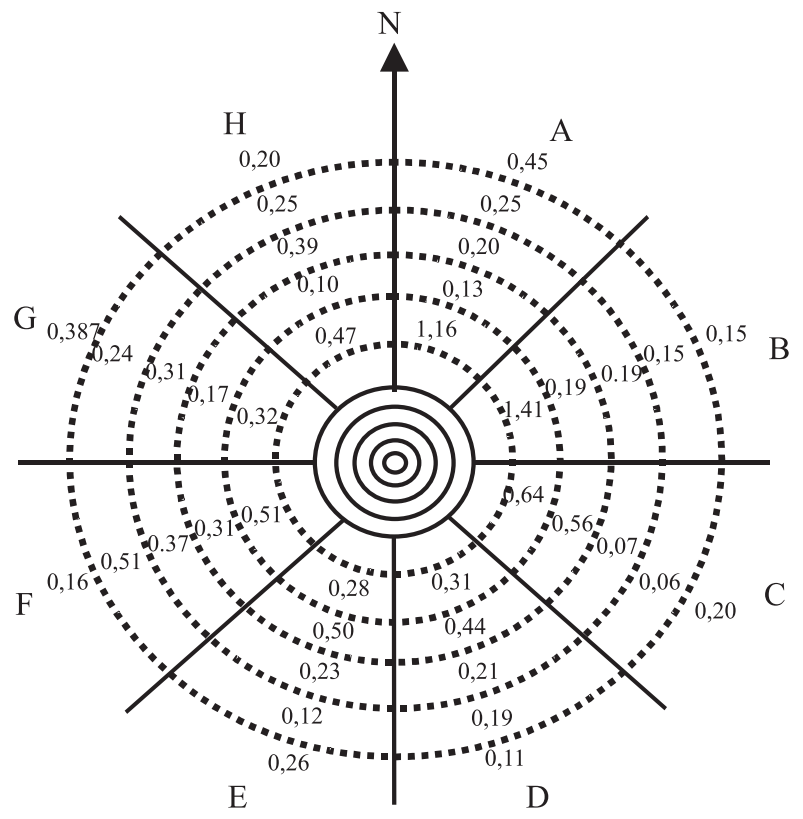

Figura 1. Representação esquemática do experimento no campo. As linhas circulares contínuas representam as plantas da cultivar CD 219RR. A distância entre essas linhas era de $50 \mathrm{~cm}$. O diâmetro do círculo mais externo, com a cultivar CD 219RR, era de $5 \mathrm{~m}$. As linhas circulares tracejadas representam as plantas da cultivar CD 211. A distância entre essas linhas era de $1 \mathrm{~m}$. O diâmetro do círculo mais externo era de $15 \mathrm{~m}$. N: norte magnético; A e B: direção nordeste; C e D: direção sudeste; E e F: direção sudoeste; G e H: direção noroeste. Os valores representam a taxa de fecundação cruzada, em porcentagem, em cada posição. de 1 a $5 \mathrm{~m}$ a partir da fonte de pólen. As médias obtidas foram comparadas pelo teste $\mathrm{t} e$ foram submetidas à análise de regressão.

\section{Resultados e Discussão}

As plantas das cultivares CD 219RR e CD 211 apresentaram desenvolvimento uniforme e homogêneo durante o experimento, e o florescimento ocorreu 64 dias após a emergência nas duas cultivares. A sincronia no florescimento possibilitou a máxima oportunidade para a transferência de pólen.

As plântulas obtidas das sementes resultantes de autofecundação, das plantas de CD 211, morreram com a aplicação do herbicida glifosato. As plântulas que sobreviveram à aplicação do herbicida originaram-se de sementes obtidas por polinização cruzada entre as cultivares CD 211 e CD 219RR. No total, das 151.772 plântulas que germinaram, 435 plântulas sobreviveram. A taxa de fecundação cruzada média, observada até $5 \mathrm{~m}$ da fonte de pólen, foi de $0,29 \%$, calculada com base no número de plantas que sobreviveram à aplicação de glifosato. A análise de PCR confirmou a presença do gene CP4 EPSPS nas plântulas sobreviventes (Figura 2).

A taxa de fecundação cruzada diminuiu de $0,61 \%$ a $1 \mathrm{~m}$ de distância, para $0,29 \%$ a $2 \mathrm{~m}$, e para $0,23 \%$ de 3 a $5 \mathrm{~m}$ (Tabela 1). Esses valores, embora baixos, são todos significativamente diferentes de zero, pela distribuição de $t$. As médias de fecundação cruzada, de 2 a $5 \mathrm{~m}$ de distância da fonte de pólen, não diferiram pelo teste t a $5 \%$ de probabilidade, mas quando a distância passou de 1 para $2 \mathrm{~m}$, a redução na taxa de fecundação cruzada foi significativa. A taxa de fecundação cruzada diminuiu de forma exponencial, a partir da fonte de pólen (Figura 3), podendo-se prever, pela equação de regressão, que a partir de 7,76 m, a alogamia é zero. Observou-se, também, que não houve predominância do fluxo gênico para uma

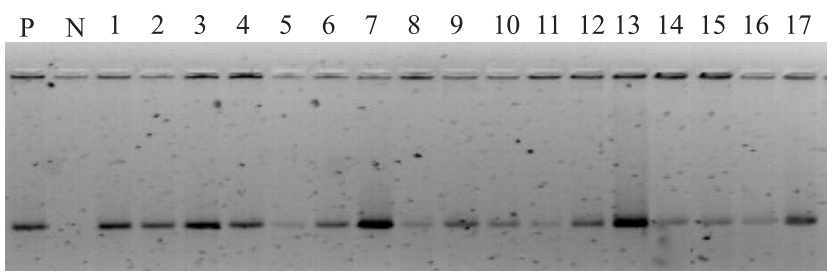

Figura 2. Análise de PCR com os primers 35S-Af2/petu r1 F e 35S-Af2/petu r1 R, das plântulas de soja sobreviventes à aplicação do glifosato. $\mathrm{P}$ : controle positivo; $\mathrm{N}$ : controle negativo; 1 a 17: amostras positivas. 
direção. O fluxo gênico ocorreu de forma aleatória, em todas as direções, a partir da fonte de pólen (Figura 1).

A soja possui flores completas e apresenta cleistogamia, isto é, a fecundação ocorre antes da abertura floral. Isso favorece a autopolinização. As taxas de fecundação cruzada em soja, além de serem baixas, são variáveis conforme o ambiente e as cultivares utilizadas. Em diversos locais, as taxas de fecundação cruzada relatadas têm sido abaixo de 1\% (Borém, 1999). Vernetti et al. (1972) relataram taxas de fecundação cruzada em soja, que variaram de $0,03 \%$ em Ponta Grossa, PR, a $1,22 \%$ em Pelotas, RS. Sediyama et al. (1970), utilizaram delineamento de fileiras adjacentes e alternadas e encontraram taxas de fecundação cruzada de $0,09 \%$ em Viçosa, MG, e $0,90 \%$ em Capinópolis, MG. Quando havia plantas alternadas, na mesma fileira, obtiveram $1,30 \%$ de fecundação cruzada em Viçosa, MG.

Ahrent \& Caviness (1994), em experimento com delineamento de fileiras adjacentes, encontraram taxas de fecundação cruzada de 0 a $2,55 \%$, ao avaliar 12 cultivares, em área com presença de abelhas. Os autores concluíram que a presença de polinizadores favoreceu a fecundação cruzada.

Para avaliar as taxas de fecundação cruzada, em diferentes distâncias da origem da fonte de pólen, Ray et al. (2003) avaliaram 12 fileiras de soja de flores brancas, ladeadas por quatro fileiras de soja de flor roxa. Foram observadas taxas de fecundação cruzada de $0,41 \%$ a $0,90 \mathrm{~m}$ e de $0,03 \%$ a $5,4 \mathrm{~m}$ da fonte de pólen. Esses autores também avaliaram a taxa de alogamia, ao semear as plantas de flores brancas e roxas na mesma fileira, intercaladas e espaçadas de $15 \mathrm{~cm}$. A taxa de fecundação cruzada encontrada foi de 1,8\%.
A recente utilização de plantas GM na agricultura trouxe, novamente, a preocupação com o fluxo gênico e a necessidade de se avaliar a possibilidade de uma lavoura convencional ser contaminada por pólen de uma lavoura GM. Recentemente, Abud et al. (2003) relataram taxas de fecundação cruzada de 0,44 a $0,45 \%$, entre plantas de soja GM e convencional, distantes $50 \mathrm{~cm}$. Os autores não observaram fluxo gênico além de 6,5 $\mathrm{m}$ de distância da fonte de pólen GM. Os autores também não observaram associação entre a direção predominante dos ventos e a frequiência de fluxo gênico, e atribuíram a distribuição aleatória do fluxo gênico à presença de insetos na área experimental. Neste trabalho, a direção do fluxo gênico também foi aleatória, e embora não tenha sido monitorada a presença de insetos, eles são comuns na área experimental, podendo-se atribuir-lhes a aleatoriedade do fluxo gênico. Erickson et al. (1978) relataram que a presença de insetos, especialmente da ordem Hymenoptera, está associada ao fluxo gênico em soja.

Em experimento com delineamento de quadrados concêntricos, Pereira (2006) avaliou a taxa de fecundação cruzada das cultivares CD 219RRR e CD 211, em Florestal, MG, e em Viçosa, MG. O autor encontrou taxa de fecundação cruzada de 1,27\% em Florestal, MG, e $0,25 \%$ em Viçosa, MG, para as fileiras que estavam distantes $0,5 \mathrm{~m}$ da fonte de pólen. A taxa de fecundação cruzada chegou a zero, com $4 \mathrm{~m}$ e $8 \mathrm{~m}$ de distância da fonte de pólen, em Viçosa e Florestal, respectivamente.

Neste trabalho foi obtida uma taxa de alogamia de $0,23 \pm 0,02 \%$, a $5 \mathrm{~m}$ de distância da fonte de pólen. Isso significa que, em $95 \%$ das estimativas, a taxa de alogamia ficará com média entre 0,21 e $0,25 \%$, entre plantas distantes $5 \mathrm{~m}$ da fonte de pólen. Ao considerar um intervalo que contenha $99 \%$ das estimativas da taxa de alogamia a esta distância, este ficará entre 0,20 e 0,26\%.

Tabela 1. Avaliação do fluxo gênico em soja, em distâncias de 1 a 5 m da fonte de pólen, em Cascavel, PR.

\begin{tabular}{|c|c|c|c|c|c|c|c|c|c|c|c|c|}
\hline \multirow[t]{3}{*}{ Direção $^{(1)}$} & \multicolumn{12}{|c|}{ Distância da fonte de pólen (m) } \\
\hline & \multicolumn{2}{|c|}{1} & \multicolumn{2}{|c|}{2} & \multicolumn{2}{|r|}{3} & \multicolumn{2}{|r|}{4} & \multicolumn{2}{|r|}{5} & \multicolumn{2}{|c|}{ Total } \\
\hline & $\mathrm{NTPG}^{(2)}$ & $\overline{\mathrm{PPS}^{(3)}}$ & NTPG & $\overline{\text { PPS }}$ & NTPG & $\overline{\mathrm{PPS}}$ & NTPG & PPS & NTPG & $\overline{\text { PPS }}$ & NTPG & PPS \\
\hline $\mathrm{A}$ & 2.075 & 1,16 & 4.543 & 0,13 & 5.948 & 0,20 & 4.888 & 0,25 & 3.763 & 0,45 & 21.217 & 0,33 \\
\hline B & 2.203 & 1,41 & 3.598 & 0,19 & 4.247 & 0,19 & 4.704 & 0,15 & 4.534 & 0,15 & 19.286 & 0,31 \\
\hline $\mathrm{C}$ & 2.183 & 0,64 & 3.212 & 0,56 & 4.136 & 0,07 & 4.753 & 0,06 & 3.588 & 0,20 & 17.872 & 0,25 \\
\hline $\mathrm{D}$ & 2.261 & 0,31 & 2.718 & 0,44 & 3.880 & 0,21 & 4.695 & 0,19 & 5.263 & 0,11 & 18.817 & 0,22 \\
\hline $\mathrm{E}$ & 2.883 & 0,28 & 3.589 & 0,50 & 3.471 & 0,23 & 4.111 & 0,12 & 4.616 & 0,26 & 18.670 & 0,27 \\
\hline $\mathrm{F}$ & 2.356 & 0,51 & 3.237 & 0,31 & 3.003 & 0,37 & 4.097 & 0,51 & 5.682 & 0,16 & 18.375 & 0,34 \\
\hline G & 2.485 & 0,32 & 3.481 & 0,17 & 3.561 & 0,31 & 4.183 & 0,24 & 4.521 & 0,38 & 18.231 & 0,29 \\
\hline $\mathrm{H}$ & 2.948 & 0,47 & 3.814 & 0,10 & 3.078 & 0,39 & 4.863 & 0,25 & 4.601 & 0,20 & 19.304 & 0,26 \\
\hline Total & 19.394 & $0,61 \pm 0,08 a$ & 28.192 & $0,29 \pm 0,03 \mathrm{~b}$ & 31.324 & $0,23 \pm 0,02 b$ & 36.294 & $0,22 \pm 0,03 b$ & 36.568 & $0,23 \pm 0,02 b$ & 151.772 & $0,29 \pm 0,01$ \\
\hline
\end{tabular}

${ }^{(1)} \mathrm{A}$ e B: direção nordeste; C e D: direção sudeste; E e F: direção sudoeste; G e H: direção noroeste. ${ }^{(2)}$ NTPG: número total de plantas germinadas. (3)PPS: porcentagem de plantas sobreviventes à aplicação de glifosato (equivale ao fluxo gênico); valores de PPS seguidos por letras iguais não diferem entre si pelo teste t a 5\% de probabilidade; valores após o sinal de mais ou menos indicam o intervalo de confiança a $95 \%$ de probabilidade. 
Esses dados permitem inferir que é muito improvável que a taxa de alogamia atinja valores próximos a $1 \%$ a essa distância, de forma que a contaminação de lavouras convencionais por pólen GM, nessa distância, não tem potencial para atingir valores acima do limite tolerável de $1 \%$, definido na legislação brasileira (Brasil, 2003a). Mesmo na distância de $1 \mathrm{~m}$ da fonte de pólen, o intervalo que contém $95 \%$ das estimativas da taxa de alogamia é de 0,53 a $0,69 \%$, e o intervalo que contém $99 \%$ das estimativas está entre 0,50 e $0,72 \%$. Ou seja, mesmo a $1 \mathrm{~m}$ de distância da fonte de pólen, é muito pouco provável que a contaminação de lavouras convencionais por pólen GM atinja níveis acima dos limites toleráveis. Se considerarmos que os grãos colhidos nessas distâncias menores serão misturados, no momento da colheita, com os grãos colhidos a distâncias maiores, esses porcentuais de contaminação serão ainda menores.

Se o objetivo é obter uma produção livre de grãos GM, uma área de isolamento de cerca de $8 \mathrm{~m}$ será suficiente para evitar a contaminação via pólen.

Na produção de sementes de soja, a área de isolamento exigida é de $3 \mathrm{~m}$ (Brasil, 2003b). Considerando-se uma área de produção de sementes convencionais, isolada por 3 m de uma lavoura de soja GM, a contaminação será inferior a $0,23 \%$ na área mais próxima da fonte de pólen (após os $3 \mathrm{~m}$ de isolamento), e será cada vez menor à medida que se afastar da fonte de pólen GM, de maneira que a contaminação deverá ser muito baixa e dependerá do perímetro da lavoura que estiver próximo da fonte de pólen.

Na certificação de sementes de soja, o porcentual máximo de sementes de outras cultivares toleradas é de

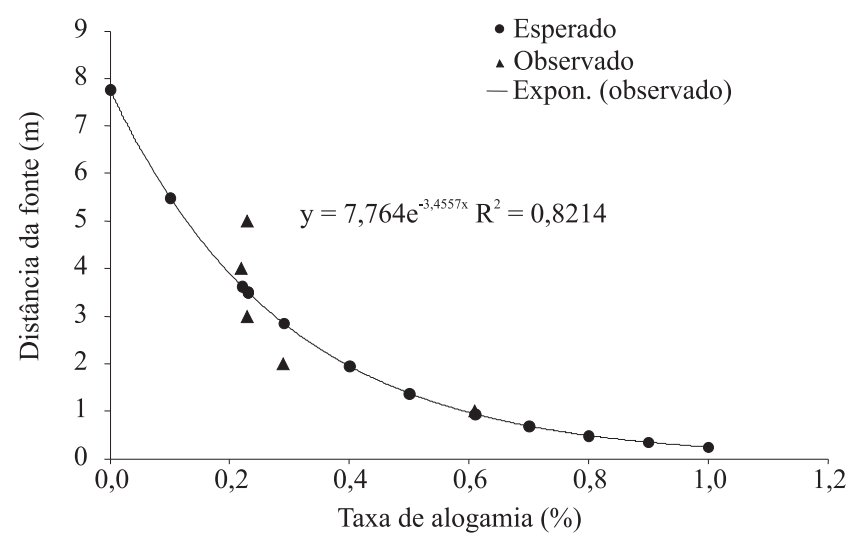

Figura 3. Redução exponencial da taxa de alogamia em soja, em função da distância da fonte doadora de pólen (m).
$0,05 \%$ para a classe $\mathrm{C} 1,0,08 \%$ para a classe $\mathrm{C} 2$ e $0,10 \%$ para as classes S1 e S2 (Brasil, 2005). Como a semente colhida no perímetro mais próximo da fonte de pólen será misturada à semente colhida a distâncias maiores, se a quantidade de sementes produzida na área compreendida entre 3 e $8 \mathrm{~m}$ da fonte de pólen representar menos de $20 \%$ do lote de sementes, não haverá necessidade de isolamento maior, mesmo para a classe $\mathrm{C} 1$. A taxa de alogamia entre duas variedades de soja convencional está na mesma magnitude da taxa de alogamia entre uma variedade GM e uma convencional (Sediyama et al., 1970; Vernetti et al., 1972; Borém, 1999), de maneira que a presença de sementes de outras cultivares, na certificação de sementes, tem a mesma chance de ocorrer, seja a fonte doadora de pólen GM ou convencional.

Assim, mesmo com muitos anos de cultivo de soja GM e convencional, em áreas próximas, a contaminação das sementes convencionais não será significativa pela via da polinização cruzada, desde que, em uma lavoura de soja convencional, as plantas GM não tenham nenhuma vantagem adaptativa; portanto, esta baixa freqüência de contaminação deverá levar à extinção das sementes GM dessas lavouras, por deriva genética.

Os resultados obtidos neste trabalho complementam a informação existente na literatura, em relação ao fluxo gênico em soja, especialmente nas condições brasileiras, e podem ser utilizados como subsídios para a elaboração de normas de isolamento, para a certificação da produção de grãos de soja convencional. Podem auxiliar, também, na definição de métodos de isolamento para a produção de sementes certificadas, e para o isolamento de parcelas GM de convencionais, nos programas de melhoramento.

\section{Conclusões}

1. A taxa de fecundação cruzada entre cultivares de soja geneticamente modificada e convencional é equivalente àquelas relatadas para a soja convencional.

2. Não há necessidade de medidas especiais de isolamento, para a obtenção de soja convencional com menos de $1 \%$ de contaminação.

3. Para uma produção de soja livre de grãos geneticamente modificados, o isolamento recomendado é de $8 \mathrm{~m}$. 


\section{Referências}

ABUD, S.; SOUZA, P.I.M.; MOREIRA, C.T.; ANDRADE, S.R.M.; ULBRICH, A.V.; VIANNA, G.R.; RECH, E.L.; ARAGÃO, F.J.L. Dispersão de pólen em soja transgênica na região do Cerrado. Pesquisa Agropecuária Brasileira, v.38, p.1229-1235, 2003.

AHRENT, D.K.; CAVINESS, C.E. Natural cross-pollination of twelve soybean cultivars in Arkansas. Crop Science, v.34, p.376378, 1994.

BORÉM, A. Escape gênico \& transgênicos. Viçosa: UFV, 2001. 206p.

BORÉM, A. Escape gênico: os riscos do escape gênico da soja no Brasil. Biotecnologia, Ciência e Desenvolvimento, v.10, p.101107, 1999.

BORÉM, A.; MIRANDA, G.V. Melhoramento de plantas. 5.ed. Viçosa: UFV, 2005. 525p.

BRASIL. Ministério da Agricultura, Pecuária e Abastecimento. Instrução Normativa no 25 , de 16 de dezembro de 2005. Diário Oficial da União, $20 \mathrm{dez}$. 2005. Disponível em: <http:// www.apassul.com.br/conteudo.asp? content $=15 \& \mathrm{a}=$ list $\& I D=13>$. Acesso em: 2 mar. 2007.

BRASIL. Presidência da República. Decreto no 4.680, de 24 de abril de 2003. Diário Oficial da União, 25 abr. 2003a. Disponível em: <http://www.mj.gov.br/DPDC/download/decreto\%2046802003.pdf>. Acesso em: 2 mar. 2007.

BRASIL. Presidência da República. Lei no 10.711 , de 5 de agosto de 2003. Diário Oficial da União, 6 ago. 2003b. Disponível em: <http:/ /www.planalto.gov.br/ccivil/LEIS/2003/L10.711.htm>. Acesso em: 2 mar. 2007.

CARLSON, J.B.; LERSTEN, N.R. Reproductive morphology. In: BOERMA, R.; SPECHT, J.E. (Ed.). Soybeans: improvement, production, and uses. $3^{\text {rd }}$ ed. Madison: CSA, CSSA, SSSA, 2004. p.59-95.

CONAB. Soja - Brasil: série histórica de área plantada, safras 1976/ 77 a 2006/07 em mil hectares. Brasília, 2006. Disponível em: <http:/ /www.conab.gov.br/conabweb/download/safra2/SojaSerieHist.xls>. Acesso em: 14 fev. 2007.

CONNER, A.J.; DALE, P.J. Reconsideration of pollen dispersal data from field trials of transgenic potatoes. Theoretical and Applied Genetics, v.92, p.505-508, 1996.

CRAWLEY, M.J.; BROWN, S.L.; HAILS, R.S.; KOHN, D.D.; REES, M. Transgenic crop in natural habitats. Nature, v.409, p.682-683, 2001.
DOYLE, J.J.T.; DOYLE, J.L. Isolation of plant DNA from fresh tissue. Focus, v.12, p.13-18, 1990.

ERICKSON, E.H.; BERGER, G.A.; SHANNON, J.G.; ROBBINS, J.M. Honey bee (Hymenoptera-Apidae) pollination increases soybean yields in Mississippi Delta region of Arkansas and Missouri. Journal of Economic Entomology, v.71, p.601-603, 1978.

JAMES C. Executive summary of global status of commercialized biotech/GM crops: 2005. Ithaca: ISAAA, 2005. 1v. (ISAAA briefs, 34).

JAMES C. Preview: global status of commercialized biotech/GM crops: 2004. Ithaca: ISAAA, 2004. 1v.(ISAAA briefs, 32).

KLEBA, J.B. Riscos e benefícios de plantas transgênicas resistentes a herbicidas: o caso da soja RR da Monsanto. Cadernos de Ciência e Tecnologia, v.15, p.9-42, 1998.

PADGETTE, S.R.; KOLACZ, K.H.; DELANNAY, X.; RE, D.B.; LAVALLEE, B.J.; TINIUS, C.N.; RHODES, W.K.; OTERO, Y.I.; BARRY, G.F.; EICHHOLTZ, D.A.; PESCHKE, V.M.; NIDA, D.L.; TAYLOR, N.B.; KISHORE, G.M. Development, identification, and characterization of a glyphosate-tolerant soybean line. Crop Science, v.35, p.1451-1461, 1995.

PEREIRA, W.A. Análise do fluxo gênico em soja RR e metodologia para sua detecção. 2006. 65p. Tese (Mestrado) Universidade Federal de Viçosa, Viçosa.

RAY, J.D.; KILEN, T.C.; ABEL, C.A.; PARIS, R.L. Soybean natural cross-pollination rates under field conditions. Environmental Biosafety Research, v.2, p.133-138, 2003.

SEDIYAMA, T.; CARDOSO, A.A.; VIEIRA, C.; ANDRADE, D. Taxa de hibridação natural em soja, em Viçosa e em Capinópolis, Minas Gerais. Revista Ceres, v.2, p.329-331, 1970.

SHEN, F.F.; YU, Y.J.; ZHANG, X.K.; BI, J.J.; YIN, C.Y. Bt gene flow of transgenic cotton. Acta Genetica Sinica, v.28 p.562-567, 2001.

SIQUEIRA, J.O.; TRANNIN, I.C.B.; RAMALHO, M.A.P.; FONTES, E.M.G. Interferências no agrossistema e riscos ambientais de culturas transgênicas tolerantes a herbicidas e protegidas contra insetos. Cadernos de Ciência e Tecnologia, v.21, p.11-81, 2004. VERNETTI, F.J.; BONATTO, E.R.; TERASAWA, F.; GASTAL, M.F. Observações sobre a taxa de cruzamentos naturais em soja, em Pelotas e Sertão, RS e Ponta Grossa, PR. Ciência e Cultura, v.1, p.36-41, 1972. 